\title{
Rice Marketing and Cross-Border Trade in Savannakhet
}

\author{
Phengkhouane Manivong and Silinthone Sacklokbam
}

\section{INTRODUCTION}

The purpose of this study was to identify the pattern of rice marketing and cross-border trade in Savannakhet Province. The province has the largest output of rice in Laos, producing a surplus for other regions in the country, and, given its location between Thailand and Vietnam, it is an important conduit for trade in the Greater Mekong Subregion (GMS). National Road 13 runs through the province along the Mekong corridor from north to south, linking the major rice-growing districts to the capital, Vientiane, and to rice-deficit provinces (see Fig. 5.1 in Chap. 5). National Road 9 traverses the province from west to east, with an international border point at either end-the Savannakhet-Mukdahan border crossing with Thailand and the Dansavanh-Lao Bao border crossing with Vietnam (Fig. 9.1). The movement of goods through these border crossings has

P. Manivong $(\bowtie)$

Faculty of Agriculture, National University of Laos, Vientiane, Laos

e-mail: manivongp@afd.fr

S. Sacklokham

SEAMEO Regional Centre for Community Education Development,

Vientiane, Laos

e-mail: s.sacklokham@nuol.edu.la

(C) The Author(s) 2020

187

R. Cramb (ed.), White Gold: The Commercialisation of Rice

Farming in the Lower Mekong Basin, https://doi.org/10.1007/978-981-15-0998-8_9 


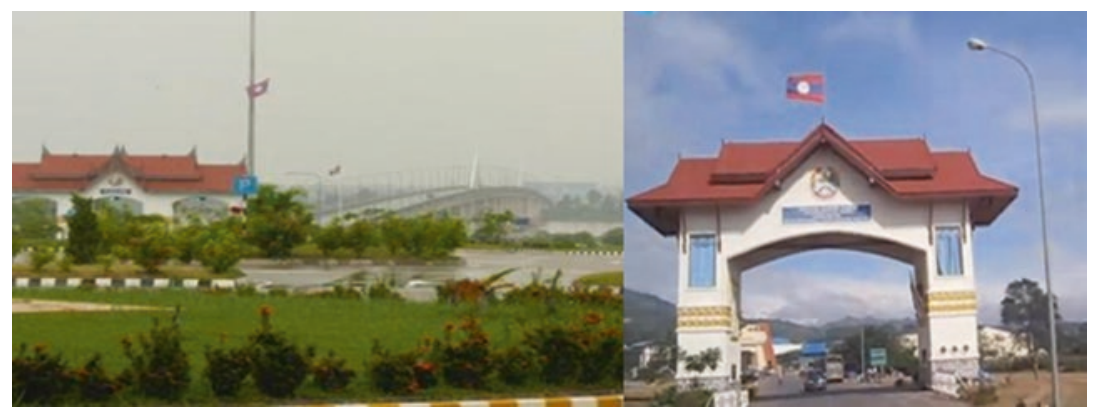

Fig. 9.1 International border points in Savannakhet Province: SavannakhetMukdahan (left); Dansavanh-Lao Bao (right)

accelerated since 2007, with Thailand and Vietnam now being Savannakhet's main trading partners. According to the Provincial Agriculture and Forestry Office (PAFO), about 25,000 tons of milled rice produced in Savannakhet Province was exported to Vietnam via the border point in 2010, which is double the volume exported in 2009. The province also imported rice from Thailand and about 5000 tons of Thai rice was moved to Vietnam through Savannakhet's borders.

The survey was conducted in March 2012 by a team of four staff from the Faculty of Agriculture of the National University of Laos. The survey focused on three locations. The first was Champhone District, which was part of the main rice-producing area in the Savannakhet Plain in the western part of the province and accounted for $16 \%$ of the province's rice output (Chap. 7). The second and third were the border crossings with Thailand and Vietnam. The target groups for interviews included all actors involved in the rice value chain, including producers, traders, millers, exporters, and officials at different administrative levels. A snowball sampling approach was used for the survey. Information from the first round of interviews was used to identify secondary respondents. This method was continued in both "upstream" and "downstream" directions until both the source and destination of the traded rice were identified. The study started with 144 farmers in six villages in Champhone District (Chap. 7). The sample farmers were selected from those farmers in each village who regularly sold rice from 2009 to 2011, using probability proportional to size (PPS) sampling. Data were obtained using semistructured interviews guided by a checklist. The information provided by the producers (the initial respondents) was then used to identify the other 
Table 9.1 Number of interviewees by category

\begin{tabular}{lc}
\hline Category & No. interviewed \\
\hline Producer & 144 \\
Collector & 2 \\
Rice miller & 11 \\
Lao exporter & 5 \\
Retailer & 23 \\
Total & 185 \\
\hline
\end{tabular}

actors involved in the rice trade. A total of 185 interviews were conducted in this way (Table 9.1). The data are used in this chapter, first, to trace the rice market chain from farms in Champhone to domestic and international markets and, second, to examine in particular the processes of cross-border trade in rice.

\section{The Rice Market Chain in Savannakhet Province}

A number of government policies affected rice marketing and trade in Savannakhet Province. The Ministry of Industry and Commerce (MOIC) had introduced a quota system for the export of rice in 2005 as a means to ensure domestic supply. In this instruction, rice exports had to adhere to the quota allocated by the Provincial Office of Industry and Commerce (PICO). A modest tax on rice exports was introduced in 2008, set at $5-8 \%$. In an extreme situation, rice exports could be banned. A temporary rice export ban was imposed from November 2010 to February 2011 to safeguard domestic supply and keep domestic prices under control. In September 2011, the government issued a further policy instruction to control the price of rice. A guaranteed minimum farm-gate price of LAK 2500 (USD 0.31) per kg and a mill-gate price of LAK 3000 (USD 0.375) per $\mathrm{kg}$ were stipulated. The State Food Enterprise (SFE) was a major player in the domestic market, buying rice at the controlled price and holding rice stocks.

The rice market chain in Savannakhet was analysed from rice farmers in Champhone District, the main production area in the province, to buyers and sellers within Laos and in Vietnam and Thailand (Fig. 9.2). The key actors were the producers, millers, domestic retailers, and exporters. Producers in Champhone sold most of their rice surplus to a rice miller within the district. Only a few sold to a collector who then immediately 


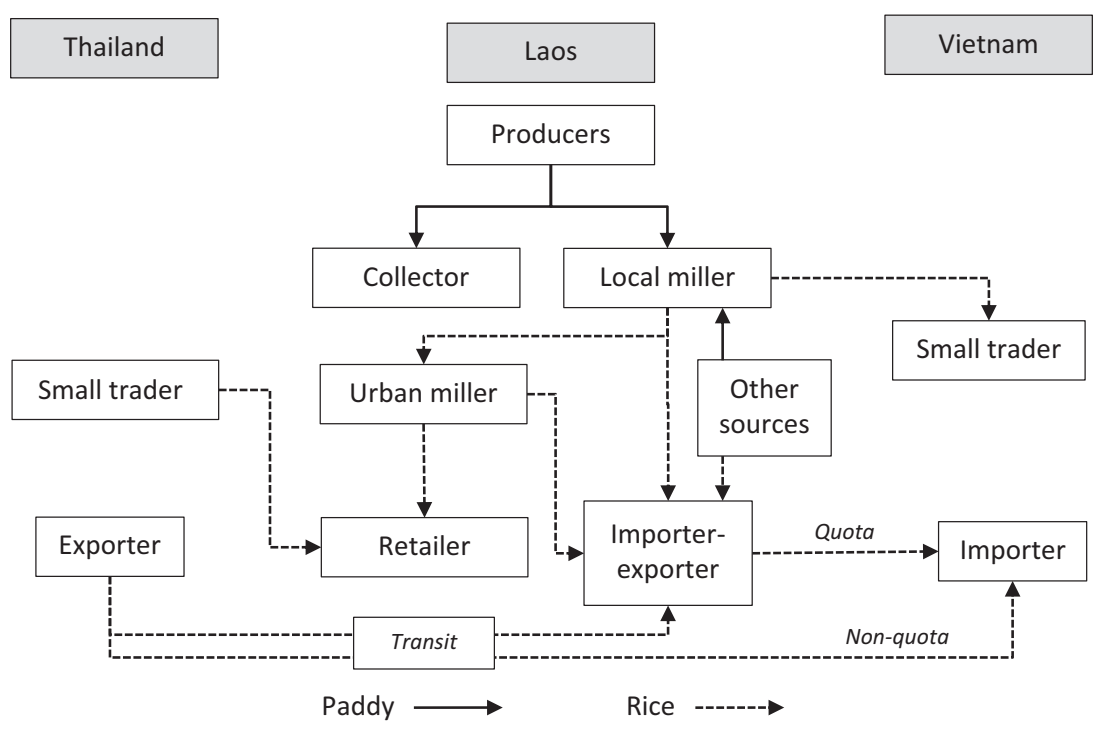

Fig. 9.2 Mapping of rice marketing and trade in Savannakhet Province

resold to a miller. The buyers typically came to the village to collect paddy rice-around 9 tons per trip for small traders and 15-20 tons for large traders.

In Champhone District, local millers were the key actors in the rice marketing system because all rice sold by producers went through a rice mill. Some of the local millers formed a trading network with their suppliers. They gave loans and farm inputs to farmers and collectors with their private funds to ensure a good quality of rice and a reliable supply. There were 57 mills registered in the district. They processed 2-4 tons of paddy rice per day, producing $60-65 \mathrm{~kg}$ of polished rice from each $100 \mathrm{~kg}$ of paddy rice. These rice mills were organized into an association at the initiative of the Trade Division of the PICO. However, purchasing and selling were still undertaken individually rather than collectively.

Farmers generally sold surplus rice twice a year. Most (90\%) sold in the period from November to January following the wet-season (WS) harvest, and over a third (35\%) also sold from May to July following the dry-season (DS) harvest. The millers bought $68 \%$ of their rice in the NovemberJanuary period and the rest in May-July, while the collectors bought 64\% 
of their rice in the May-July period and the rest in November-January. Thus, more of the millers relied on collectors to make the farm-level purchases of the DS harvest.

The producer was considered a price-taker because the millers offered a farm-gate price for paddy rice based on quality criteria (e.g., average moisture content and percentage of foreign matter). The millers would set an acceptable level for each quality criterion, discount the price for each percentage point over the acceptable level, or reject the rice if damage or moisture was above a certain limit. The price was usually displayed at the front of the mill. For the polished rice, the rice mill proposed a wholesale price for the local market. However, the retail price of rice in the local market was under the control of the Trade Division of PICO in an attempt to avoid price spikes.

Farm-gate prices fluctuated seasonally in predictable ways (Table 9.2). Prices were lowest in the months following the WS (November-January) and DS (May-July) harvests, when farmers sold most of their surplus rice and supplies were abundant. Prices peaked in August-October when supplies were scarce in the lead-up to the WS harvest. Table 9.2 also shows the year-to-year fluctuation around the 2010 price spike. The peak price in 2010 was LAK 4500 per kg of paddy rice in August-October, which was $28 \%$ higher than for the same period in 2009. Exports of rice also peaked in this year. However, the price dropped by a third to LAK 2400-3000 per $\mathrm{kg}$ in 2011 because of the export ban introduced in November 2010 to regulate the domestic price. The price increased slightly in 2012 and had stabilized at LAK $2500-3000$ per $\mathrm{kg}$.

Table 9.2 Farm-gate prices of paddy rice by month, 2009-2011 (LAK/kg)

\begin{tabular}{llll}
\hline Month & 2009 & 2010 & 2011 \\
\hline $\begin{array}{l}\text { January } \\
\text { March }\end{array}$ & 2800 & 3000 & 2000 \\
April & & & \\
May & 2000 & 2500 & 1700 \\
June & 2000 & 2500 & 1700 \\
July & 2000 & 2500 & 1700 \\
August & $3200-3500$ & $3800-4500$ & $2400-3000$ \\
September & $3200-3500$ & $3800-4500$ & $2400-3000$ \\
October & $3200-3500$ & $3800-4500$ & $2400-3000$ \\
November & 2800 & 3000 & 2000 \\
December & 2800 & 3000 & 2000 \\
\hline
\end{tabular}


When the export of rice was surging in 2010, polished rice from the mills in Champhone District was mainly sold to export companies. Some was sold to individual traders for the informal trade. Typically the buyers came to the rice mill to make their purchases and check for product quality. However, by 2011 , only 11 of the 57 mills had trading activities. Most mills, especially the small mills, had temporarily stopped trading activities due to the ban on exports imposed in late 2010. These mills bought rice and stocked it for the local market. However, they claimed to be using only $30 \%$ of their capacity as they still held stocks from the 2010 harvest.

As noted above, rice was exported from Champhone District through both trading companies and individuals (Fig. 9.2). These two channels can be classified as formal and informal trade. The formal trade was conducted by Lao import-export companies, which were classified as medium enterprises. In Savannakhet Province, there were five companies involved in the border trade in rice. Most were located in the central districts of the province but also had their representative offices in Ban Dansavanh, close to the Dansavanh-Lao Bao border checkpoint. These companies undertook four major forms of formal trading activity: imports, exports, re-exports, and transit trade. For the export of goods, the companies were required to submit all documents such as letters of request, invoices, and packaging documents to the Trade Division of PICO for their quota allocation, after which the approved documents were sent to a one-stop service centre at the border point (see below).

The informal trade was conducted by small traders at the international checkpoint. Small-scale traders often carried goods by themselves across the border and walked to local markets. It was quite common for traders from Vietnam to bring a range of consumer goods, including food items such as vegetables, garlic, fruits, noodles, and cookies, as well as clothes and plastic ware. The flows in the opposite direction commonly included rice, bananas, and non-timber forest products. These traders were usually exempt from any kind of customs or import fees, needing only to pay the border crossing fee of LAK 5000-10000 (about USD 1) per crossing.

According to the export companies interviewed, the rice from Savannakhet was sold to private companies in Vietnam who either sold the rice in their domestic market or processed the rice into starch (Fig. 9.2).

A matrix of the networks between different actors in the rice market chain is depicted in Table 9.3. In some villages, producers were organized into a farmers' group which exchanged seeds, inputs, and labour among its members. The groups were formed with the support of international 
Table 9.3 Matrix of trading networks and linkages in rice market chain

\begin{tabular}{|c|c|c|c|c|c|c|}
\hline $\begin{array}{l}\text { Type of } \\
\text { actor }\end{array}$ & Producer & Collector & Miller & Exporter & Importer & Retailer \\
\hline Producer & $\begin{array}{l}\text { Producer } \\
\text { group }\end{array}$ & $\begin{array}{l}\text { Receives } \\
\text { credit, } \\
\text { inputs }\end{array}$ & $\begin{array}{l}\text { Receives } \\
\text { credit, } \\
\text { inputs }\end{array}$ & NA & NA & NA \\
\hline Collector & $\begin{array}{l}\text { Buys } \\
\text { paddy } \\
\text { rice }\end{array}$ & $\begin{array}{l}\text { Managed } \\
\text { competit- } \\
\text { ion }\end{array}$ & $\begin{array}{l}\text { Sells paddy } \\
\text { rice }\end{array}$ & NA & NA & NA \\
\hline Miller & $\begin{array}{l}\text { Buys } \\
\text { paddy } \\
\text { rice }\end{array}$ & $\begin{array}{l}\text { Buys } \\
\text { paddy rice }\end{array}$ & $\begin{array}{l}\text { Millers' } \\
\text { group }\end{array}$ & $\begin{array}{l}\text { Oral } \\
\text { contract to } \\
\text { supply } \\
\text { milled rice }\end{array}$ & NA & $\begin{array}{l}\text { Supplies } \\
\text { quota of } \\
\text { milled rice }\end{array}$ \\
\hline Exporter & NA & NA & $\begin{array}{l}\text { Oral } \\
\text { contract to } \\
\text { buy milled } \\
\text { rice }\end{array}$ & NA & $\begin{array}{l}\text { Written } \\
\text { contract to } \\
\text { supply } \\
\text { milled rice }\end{array}$ & NA \\
\hline Importer & NA & NA & $\mathrm{NA}$ & $\begin{array}{l}\text { Written } \\
\text { contract to } \\
\text { buy milled } \\
\text { rice }\end{array}$ & $\begin{array}{l}\text { Managed } \\
\text { competit-ion }\end{array}$ & $\begin{array}{l}\text { Supplies } \\
\text { agreed } \\
\text { quantity }\end{array}$ \\
\hline Retailer & NA & NA & $\begin{array}{l}\text { Obtains } \\
\text { quota of } \\
\text { milled rice }\end{array}$ & NA & $\begin{array}{l}\text { Orders } \\
\text { imported } \\
\text { milled rice }\end{array}$ & Competition \\
\hline
\end{tabular}

development projects. However, they did not have any marketing function and farmers made independent decisions to sell rice.

Collectors and rice millers provided services to individual farmers in their own networks by giving loans and farm inputs (seeds, fertilizers, and pesticides) at the start of the crop season. The farmers repaid their loan after harvest with interest of $3-10 \%$. The motivation of the millers for supplying inputs on credit was to ensure the supply and a homogenous grade of rice.

Rice millers and exporters made supply agreements but without written contracts. In the opinion of the exporters, a written contract would not be respected, even by regular suppliers. Some used to make written contracts with their suppliers but they were not adhered to due to the uncertainty of the market. However, the exporters had written contracts with their foreign customers as it was a compulsory part of the export procedure.

A number of constraints to the rice marketing chain were identified, mainly around quality and grading issues. (a) Farmers used a range of 
varieties (e.g., long- and short-grained, glutinous and non-glutinous) which resulted in mixing of varieties when the rice arrived at the mill. (b) Much of the grain was delivered with high moisture content (15-16\%). Moreover, farmers sometimes mixed dried grain with wet grain. (c) The poor processing facilities in the mills made it difficult to meet international quality standards. Lao rice is generally classed as Grade 5. (d) The fluctuation in prices, in part caused by unpredictable policies, created uncertainty for producers, traders, and processors.

\section{Border Trade in Savannakhet Province}

Laos has two types of border crossing-international and local. The international crossings are generally open to all foreign nationals in possession of a valid passport and visa, while local crossings are open only to local people on each side of the border who are able to cross back and forth using some form of border pass. Laos has 16 international border points and 20 local border points. These border points link Laos to neighbouring countries, including Thailand (via seven international border points), Vietnam (via seven international border points), China (via one international border point), and Cambodia (via one international border point). The cross-border trade is virtually synonymous with international trade due to the country's landlocked situation.

As mentioned above, Savannakhet Province has two international border points. Dansavanh-Lao Bao is located along Route 9, the east-west corridor of Mainland Southeast Asia, in Ban Dansavanh, Sepon District. This border point was opened to the public in 2002, linking Savannakhet Province to Quang Tri Province in Vietnam. Savannakhet-Mukdahan is located in Khaisonphonvihanh District, the municipal area of the province. This border point was opened to the public in 2005 and links Savannakhet Province to Mukdahan Province in Thailand via the Mekong Bridge II.

There are three major forms of formal trading activity via these border points: imports, exports, and transit trade. The main products exchanged are summarized in Table 9.4. Rice is among the main products exported from Savannakhet Province to Vietnam via the Dansavanh-Lao Bao border point, along with other unprocessed crops such as banana, cassava, and coffee. The main imported goods through this point include food products and fertilizers (as well as manufactured items such as household utensils and vehicles). On the other hand, rice is not among the main goods exported to Thailand, while coffee, cassava, and fruit are. The goods 
Table 9.4 Main products exchanged via international border points of Savannakhet Province, 2010

\begin{tabular}{llll}
\hline Border point & Exported products & Imported products & Transit products \\
\hline Dansavanh/Lao Bao & Rice & Garlic & Rice \\
& Bananas & Shallots & Fruits \\
& Cassava & Fertilizers & Wild orchids \\
& Coffee & & Horticulture \\
& Fruits & & \\
Savannakhet/Mukdahan & Coffee & Sugarcane & Horticulture \\
& Cassava & Rice & Fruits \\
& Fruits & Rattan & Garlic \\
& & Rubber & Wild orchids \\
& & Fertilizers & Shallots
\end{tabular}

Table 9.5 Value of cross-border trade in Savannakhet Province, 2010 and 2011

\begin{tabular}{llcl}
\hline \multirow{2}{*}{ Border point (year) } & \multicolumn{3}{l}{ Value of trade (USD million) } \\
\cline { 2 - 4 } & Exports & Imports & Transit \\
\hline Dansavanh-Lao Bao (2010) & 26.0 & 11.9 & 7.0 \\
Dansavanh-Lao Bao (2011) & 26.6 & 10.1 & 7.0 \\
Savannakhet-Mukdahan (2010) & 0.6 & 2.0 & 0.7 \\
Savannakhet-Mukdahan (2011) & 2.7 & 3.0 & 2.4 \\
\hline
\end{tabular}

Source: Provincial Industry and Commerce Office, Savannakhet

imported from Thailand, however, include rice as well as other agricultural products and fertilizers. Transit products are those traded between Thailand and Vietnam through Savannakhet, including rice, fruits, and horticultural products. According to statistics provided by the PICO, the value of trade through the Dansavanh-Lao Bao border point (USD 26.6 million in 2011) was ten times more than that through the SavannakhetMukdahan border point (Table 9.5).

The policies and procedures for cross-border trade have evolved over the past 15 years. In 2001, the Ministry of Industry and Commerce (MOIC) issued Instruction No. 948 on Small Export Border Businesses to promote small-scale export businesses and the management of cross-border trade. In this instruction, two types of border points were distinguished - remote and non-remote. In a remote border point, import and export of all products necessary for production and consumption was 
allowed (within the list of permitted goods). In a non-remote border point, only inputs necessary for production were allowed to be imported; consumption goods were to be bought only from domestic markets. In October 2004, the MOIC issued Order No. 962 on importation and exportation to establish one-stop services at border points, including the services of all trade-related agencies, and to abolish export-import licences. ${ }^{1}$ The GMS Cross-Border Trade Agreement (CBTA) took effect in 2005 with the opening of one-stop services.

For the import of goods, trading companies need to submit their plans to the Trade Division of the PICO. Approval of the import plan is based on the policy of the provincial authority with regard to the import-export balance of the province. Each year the national government sets indicative import plans for various products to manage the national trade balance. The overall plan target is then allocated to import-export companies in each province by the respective PICO. In principle, the allocation is based on the ability of a company to access the market, but in practice the allocation often does not reflect that capability.

For the export of goods, the export companies are required to submit all documents including letters of request, invoices, and packaging documents to the Trade Division of PICO, after which the approved documents are sent to the one-stop service centre at the border. Clearance procedures at the checkpoint take only 30 minutes to an hour, as long as the traders have completed the documents required.

The rice export procedure for Savannakhet Province at the time of the survey is illustrated in Fig. 9.3. After receiving an order from foreign customers, the company checked the availability of sufficient rice of suitable quality from its own trading networks. It then submitted its export plan to the Trade Division of PICO for a quota allocation. The overall export quota for the province was determined as follows: (a) the rice surplus at the provincial level was estimated as total production minus the quantity of auto-consumption (estimated at $280-320 \mathrm{~kg} /$ person/year); (b) the quantity required for local consumption at the provincial level was estimated and deducted; (c) the official quota was calculated as the residual surplus. For Savannakhet Province, the export quota was typically around $20,000-30,000$ tons per year $(10-15 \%$ of the rice surplus). This was then divided into allocations for individual export companies. After approval of its quota, the exporter had to contact the PAFO for sanitary and phytosanitary (SPS) certification. The company then went to the Taxation and Customs Unit of the Ministry 


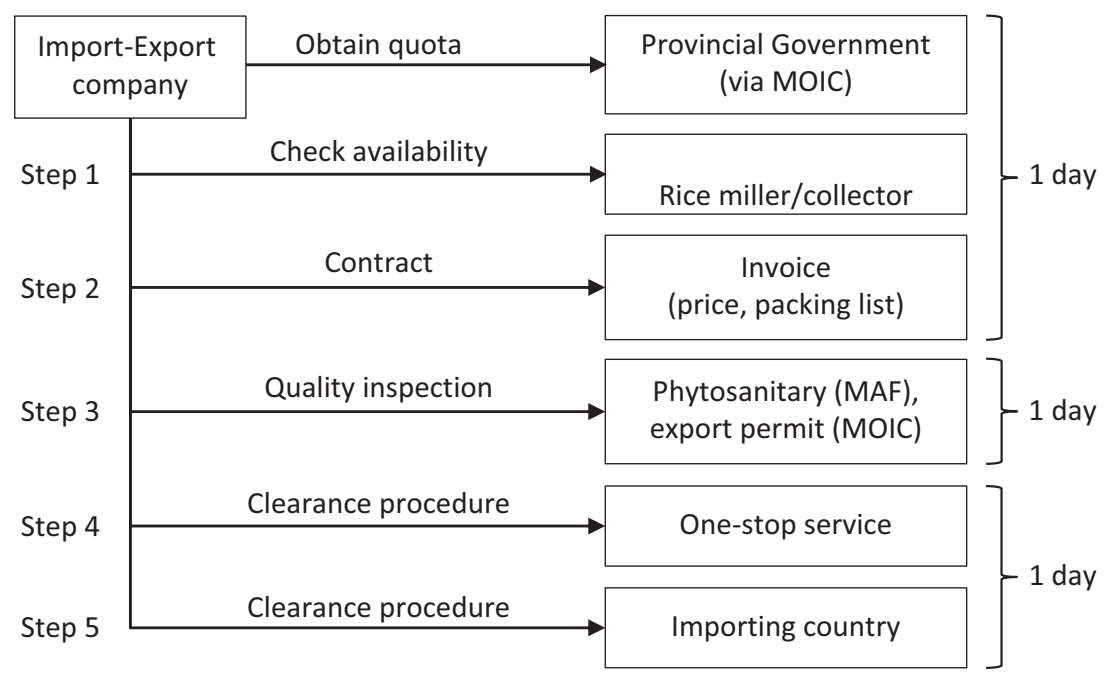

Fig. 9.3 Procedure to export rice from Savannakhet Province. (Source: Trade Division, PICO Savannakhet)

Table 9.6 Cross-border trade in rice, Savannakhet Province, 2009-2011

\begin{tabular}{lrrr}
\hline & 2009 & 2010 & 2011 \\
\hline Exports (tons) & 12,023 & 24,800 & 88 \\
Imports (tons) & 9498 & 3300 & 0 \\
Transit (tons) & 5137 & 465 & 1605 \\
\hline
\end{tabular}

Source: Provincial Agriculture and Forestry Office, Savannakhet Province, Annual Reports 2007-2012

of Finance for tax and customs clearance. Finally, the company applied to the Trade Division of PICO for the export permit and licence. Each time it went through this cycle, the company paid about LAK 500,000 (USD 60) in fees.

Exports of rice have fluctuated, with a peak in 2010 of 24,800 tons, accounting for $10 \%$ of the rice surplus in Savannakhet Province and about $5 \%$ of total production (Table 9.6). The major market was Vietnam (see Chap. 20). However, the price of rice in local markets doubled between 2009 and 2010 due to a combination of factors, including official purchases of rice for southern flood victims and rice hoarding in preparation for the upcoming wet season. Despite the relatively small volume of exports, the 
cross-border trade was seen to have contributed to the increased price of rice at the national level. The government decided to regulate the domestic supply and keep the price under control by imposing a temporary export ban from November 2010 to February 2011. This accounts for the insignificant volume of exports from Savannakhet in 2011 (Table 9.6). The trade in rice followed seasonal fluctuations. The export of rice to Vietnam tended to be the greatest from November to January due to the high demand during the celebration of Tet, when glutinous rice is consumed. The import of rice from Thailand tended to peak from July to September due to shortage in the domestic market in the lead-up to the WS harvest.

\section{Conclusion}

The analysis revealed potential to expand the marketing and export of rice from Savannakhet Province. Most rice farmers in Champhone District were market-oriented, regularly producing for the market rather than only for home consumption. They used improved varieties and fertilizers and sold a substantial part of both their WS and DS crops. There was a good opportunity to increase the export of rice to neighbouring countries due to a favourable trade environment through Association of South East Asian Nations (ASEAN) and bilateral agreements. Champhone District had already been opened to the regional market and reasonably efficient trading networks were in place.

However, there were several constraints to the marketing and export of rice in Champhone District and the province as a whole. Farmers often delivered rice of mixed grades and high moisture content. The rice mills in Savannakhet had poor processing equipment, making it difficult to meet international quality standards. The export ban in 2010-2011 caused a sudden drop in prices and created market uncertainty. This reduced the willingness of farmers to produce surplus rice for the market and made it difficult for traders and millers to plan their marketing and export strategy.

These constraints could perhaps be alleviated through government policies to promote suitable varieties to ensure a homogeneous rice grade for the export trade; enhance post-harvest technology (storage and drying) to improve the rice moisture content; improve the processing infrastructure for sorting, milling, and polishing; and create a more stable policy environment for the export sector. 


\section{Note}

1. The exceptions were gold and copper exports from Savannakhet, and vehicles, spare parts, petroleum, gas, diamonds, and other controlled goods that still required import licences from the Ministry of Commerce.

Open Access This chapter is licensed under the terms of the Creative Commons Attribution 4.0 International License (http://creativecommons.org/licenses/ by $/ 4.0 /$ ), which permits use, sharing, adaptation, distribution and reproduction in any medium or format, as long as you give appropriate credit to the original author(s) and the source, provide a link to the Creative Commons licence and indicate if changes were made.

The images or other third party material in this chapter are included in the chapter's Creative Commons licence, unless indicated otherwise in a credit line to the material. If material is not included in the chapter's Creative Commons licence and your intended use is not permitted by statutory regulation or exceeds the permitted use, you will need to obtain permission directly from the copyright holder.



